\title{
ВІДНОВЛЕННЯ ЦИЛІНДРИЧНИХ ДЕТАЛЕЙ ПОЛІГРАФІЧНОГО ОБЛАДНАННЯ НА ОСНОВІ СЕЛЕКТИВНИХ МЕТОДІВ
}

๑ П. О. Киричок, д.Т.н., професор, А. В. Несхозієвський, к.т.н., ст. викладач, А. В. Шевчук, А.т.н., професор НТУУ «КПІ», Київ, Україна

\section{В статье исследованы некоторые методы восстановления цилиндров офсетных печатных машин, приведены перспективы дальнейших разработок.}

Methods of recovery of the cylinders in offset printing machines are analyzed, perspectives of the next researches are mentioned.

\section{Постановка проблеми}

Сучасне обладнання, що застосовується в друкарських та післядукарських поліграфічних процесах, є складною та дорогою ланкою в ланцюгу технології випуску поліграфічної продукції. Забезпечення безперервної та ритмічної роботи вищевказаного обладнання є безумовною вимогою до успішної роботи будь-якої друкарні.

Надійність та довговічність металевих деталей машин, механізмів, металорізального та металотиснучого інструмента значною мірою залежить від якості поверхні та поверхневого шару.

Як правило, причиною руйнування елементів конструкцій при експлуатації є процеси, що здійснюються на поверхні та у поверхневому шарі: утворення натирів, задирів, зношування, перерозподіл залишкових напруг та їх концентрація, розвиток мікротріщин, вигорання легуючих елементів, знеміцнення тощо.
Окрім поламок механізмів машин, пов'язаних 3 механічним зносом та неякісним виготовленням деталей, $€$ дефекти, які з'являються в результаті порушення правил експлуатації поліграфічного обладнання та неуважності обслуговуючого персоналу. Це - пошкодження сторонніми предметами поверхонь циліндрів (офсетних, друкарських, формних, ламінувальних, лакових, каландрових тощо), а також абразивне та корозійне зношування. Детальне вивчення та усунення причин даних проблем дозволить суттєво зменшити ризики їх появи у майбутньому, а також дозволить встановити способи найбільш ефективного технологічного забезпечення при їх виникненні.

\section{Аналіз попередніх досліджень}

В основному дослідження даної проблеми носять прикладний характер, проте є розробки, використання яких до- 
зволяє суттєво покращити зносостійкість та міцність деталей, знизити ризик значного ушкодження циліндрів під час експлуатації. Серед них - фізичні методи обробки (лазерне зміцнення, наплавка), фізикохімічні методи обробки (іонноплазмова обробка, електрохімічні методи зміцнення, хімічний осад із розчинів та ін.), зміцнення поверхонь поверхневим пластичним деформуванням (вібраційна обробка, вигладжування надтвердими матеріалами, дернування та ін.) [1]. Також існують методи відновлення циліндрів без зняття їх з друкарської машини чи іншого поліграфічного обладнання [2].

\section{Мета роботи}

Метою даної статті $€$ дослідження найбільш сучасних ефективних, економічно доцільних та прогресивних методів відновлення циліндрів офсетних друкарських машин.

\section{Результати проведеного дослідження}

Як відомо, причиною вказаних на початку статті дефектів можуть бути залишені в робочій зоні ключі, пачка паперу, ґудзик, що випав з форми працівника, шарики з підшипника, залишки застиглого клею, викручені гвинти та ін. Попадання подібних предметів в машину, що працює, може призвести до серйозних порушень цілісності поверхні циліндрів, пошкодженням офсетного полотна та друкарської форми (рис. 1-3).

Корозійне зношування, як правило, виникає через несвоєчасне видалення лужних чи кислих розчинів, що потрапили під офсетне гумово-тканинне полотно (рис. 4).

Для вирішення цих питань необхідне як подальше вдосконалення конструкцій машин, раціональний вибір і застосування більш якісних матеріалів, так і розробка та застосування нових техно-

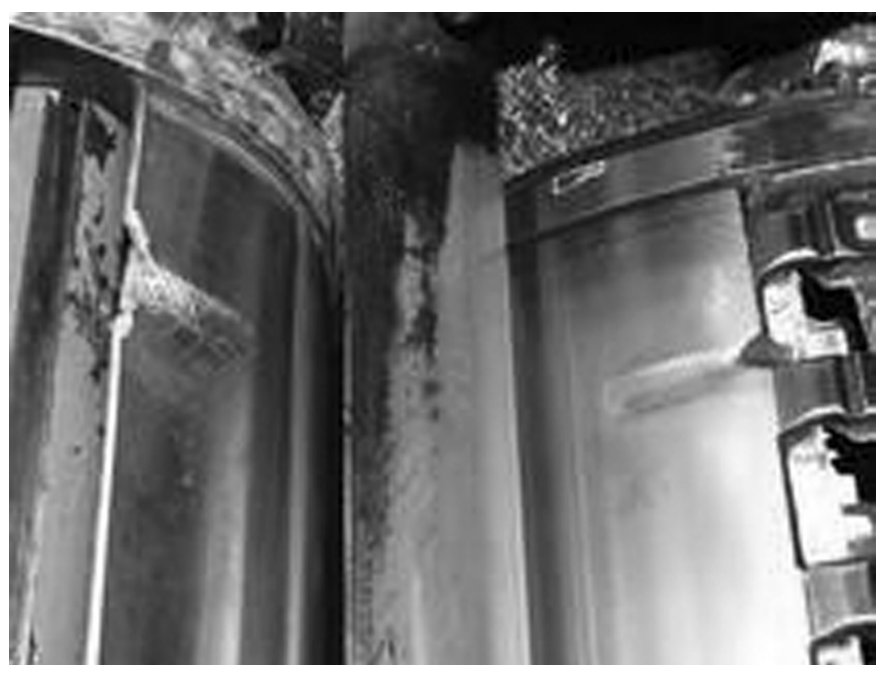

Рис. 1. Продавлені офсетний та формний циліндри офсетної друкарської машини 


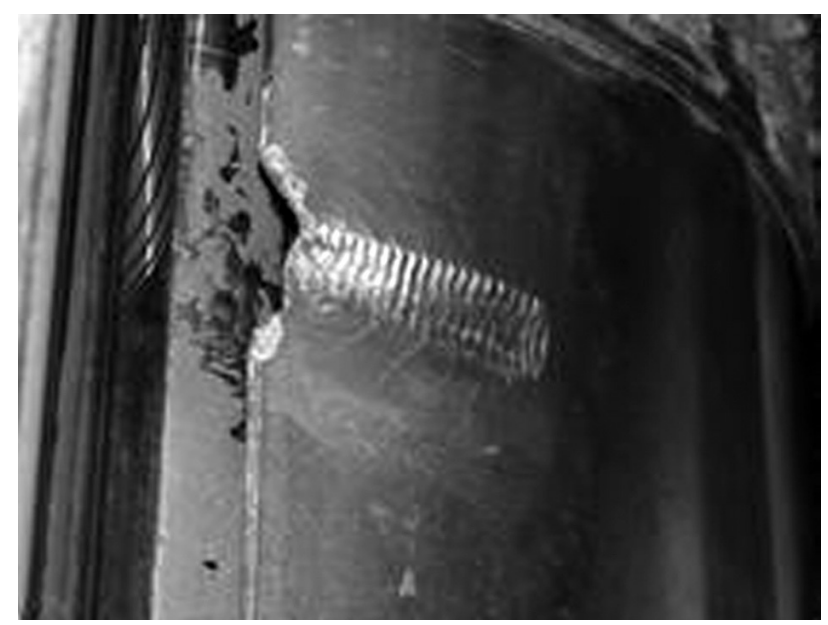

Рис. 2. Пошкодження офсетного циліндру гвинтом із машини

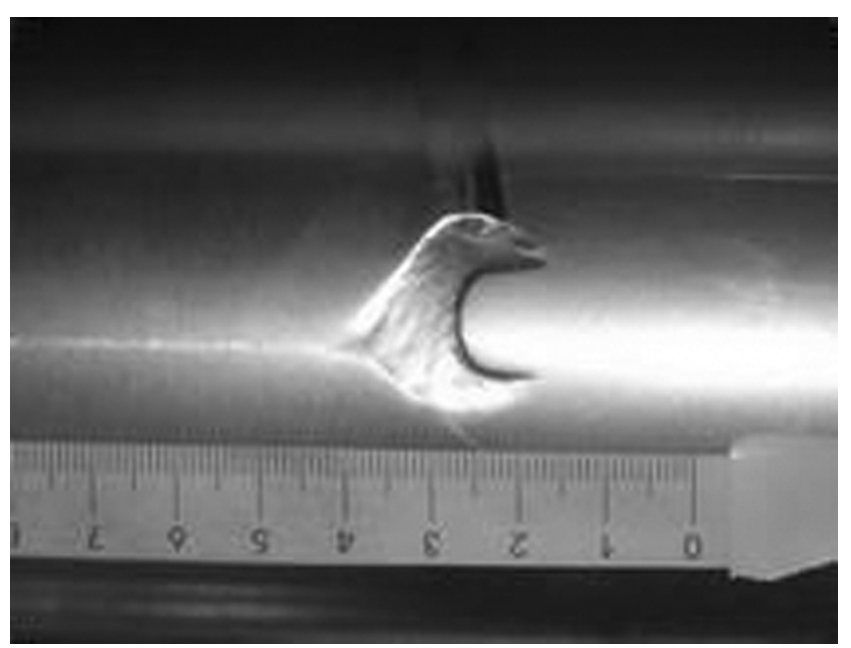

Рис. 3. Пошкодження формного циліндру ключем

логічних процесів, особливо тих, що призначені для обробки чи зміцнення поверхонь металевих деталей поліграфічного обладнання.

Як правило, результати незначних продавів та подряпин глибиною до 0,1 мм при невисоких вимогах до якості продукції друкарі намагаються компенсувати збільшенням натиску, що в кінцевому випадку призводить до зменшення робочого ресурсу друкарської машини. Більш серйозні дефекти іноді прибирають за допомогою композитних матеріалів. Недоліками даного методу є залежність адгезії від товщини шару композиту, що наноситься на циліндр, його низька твердість, незадовільна хімічна стійкість. Інші види ремонту більш тривалі та пов'язані 3 


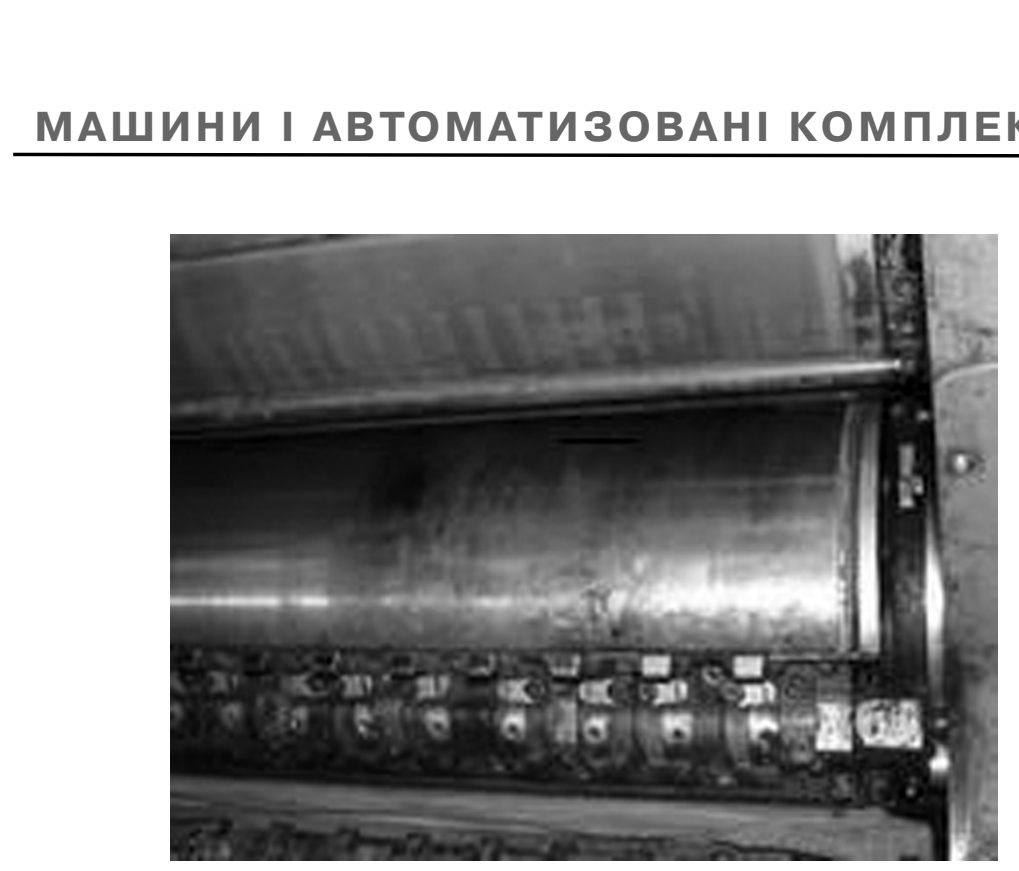

Рис. 4. Приклади корозії офсетного циліндру

під офсетним гумовотканинним полотном та каліброваним картоном

частковим чи повним демонтажем обладнання.

Стандартний процес відновлення циліндрів $€$ достатньо довгим та дорогим: зношені чи деформовані циліндри демонтують та відправляють на ремонтні підприємства. Там їх нарощують та шліфують. Даний процес має значну рудомісткість та потребує високої кваліфікації персоналу. Після цього відбувається транспортування валів до місця експлуатації, встановлення їх на місце з наступним точним регулюванням та довгим налаштуванням. В цілому процес $є$ дуже довгим та потребує значних фінансових витрат для підприємства.

Рішенням проблеми прибирання локальних дефектів циліндрів без демонтажу чи часткової розборки обладнання $€$ метод селективної електрохімічної металізації. Дана технології широко застосо- вується за кордоном у машинобудуванні, в нафтовій та газовій промисловості, електроніці, в ремонт гідроапаратури будівельної та дорожньої техніки, при відновленні поліграфічного, текстильного та хімічного обладнання. 3 її допомогою видаляються задири, подряпини, продави, абразивне та корозійне зношування, відновлюються зношені посадкові місця підшипників, проводиться зміцнення поверхневого шару металу.

Технологічний процес селективної електрохімічної металізації відрізняється від традиційних гальванічних процесів відсутністю ванни 3 електролітом [2]. Електрохімічне осадження металів (нікелю, міді, сплаву нікель-кобальт та ін.) відбувається під дією постійного струму. Місце дефекту відділяється (маскується) від неушкодженої поверхні, гострі кромки зачищаються, ви- 
даляються масляні залишки. Спеціальними розчинами з використанням різної полярності току дефектна поверхня активується і потім на ній створюється адгезій ний шар. Далі виконується натирання його електродом (анод) в оболонці $з$ пористого абразивного матеріалу, а в зону контакту безперервно подається електроліт. Катодом є ушкоджена деталь. Нанесення металу відбувається до повного заповнення дефекту. При необхідності виконується механічна обробка. Випадіння гальванічних осадів 3 електроліту можливе практично на будь-які метали, включаючи алюміній та нержавіючу сталь. Як правило, дефектне місце заповнюється гальванічною міддю 3 показником твердості 350-380 НВ, а в якості фінішного покриття $=$ нікель чи сплав нікелю та кобальту з твердістю HRc 54-58 [2]. Гальванічна мідь використовується через власну високу швидкість осадження (до 27 мкм/хв). Глибина та площа поверхні, що відновлюється, практично не лімітується. Аналогічним шляхом можливе проведення косметичного ремонту поверхонь циліндрів в якості передпродажної підготовки обладнання, що було у вжитку.

Контроль заданих параметрів при відновленні циліндрів поліграфічних машин, як правило, проводиться відносно неушкодженої (базової) поверхні за допомогою спеціаль- них приладів чи магнітної стійки з часовим індикатором та ціною поділки 0,002 мм. Окрім розмірної точності критерієм якості поверхні, що відновлюється, Є контрольний друкарський відбиток, що отримується без використання зволоження з невеликим натиском. При необхідності проводиться механічна обробка чи наноситься додатковий фінішний шар.

Доцільність проведення ремонту визначається критерієм час-вартість.

\section{Висновки}

Наведені методи відновлення циліндрів офсетних друкарських машин та іншого обладнання дозволяють суттєво прискорити процес ремонту та відновлення працездатності техніки. Одним із найбільш перспективних на сьогодні $є$ метод електрохімічної селективної металізації, який дозволяє проводити ремонтні роботи об'єкту без демонтажу обладнання 3 місця його постійної експлуатації. При цьому забезпечується мінімальний час підготовки, простота процесу, можливість приступати до роботи на обладнання одразу після ремонту. Подальші дослідження мають довести можливість поєднання даного методу із іншими більш класичними, та підготовити базу для створення цілої системи технологічного забезпечення відновлення деталей поліграфічного обладнання. 
1. Киричок П. О. Зміцнення поверхонь металевих деталей / П. О. Киричок, В. Г. Олійник, Т. Ю. Киричок - К. : Преса України, 2004. - 240 с. 2. Тараскин В. Восстановление поверхности цилиндров без демонтажа полиграфического оборудования с применением технологии селективной электрохимической металлизации / В. Тараскин // Полиграфия на Волге. - 2008. - № 3. - с. 12-13. 3. http://www.printcomrussia.com/ archive/81/ 4. Белокрысенко В. Ф. Почему «разбиваются» печатные машины / В. Ф. Белокрысенко, В. Н. Токарев и др.// КомпьюАрт. 2007. - № 3. - c. 46-50.

1. Kyrychok P. O. Zmitsnennia poverkhon metalevykh detalei / P. O. Kyrychok, V. H. Oliinyk, T. lu. Kyrychok. - K. : Presa Ukrainy, 2004. 240 s. 2. Taraskin V. Vosstanovlenie poverhnosti cilindrov bez demontazha poligraficheskogo oborudovanija s primeneniem tehnologii selektivnoj jelektrohimicheskoj metallizacii / V. Taraskin // Poligrafija na Volge. — 2008. - № 3. S. 12-13. 3. Elektronnyi resurs. - Rezhym dostupu : http://www.printcomrussia.com/archive/81/. 4. Belokrysenko V. F. Pochemu «razbivajutsja» pechatnye mashiny / V. F. Belokrysenko, V. N. Tokarev i dr. // Komp'juArt. - 2007. № 3. - S. 46-50.

Рецензент - В. П. Шерстюк, д.х.н., професор, НТУУ «КПІ»

Надійшла до редакції 27.09.12 